\title{
Predisposing factors for peripheral intravenous puncture failure in children ${ }^{1}$
}

\author{
Daniela Cavalcante de Negri \\ Ariane Ferreira Machado Avelar ${ }^{3}$ \\ Solange Andreoni ${ }^{4}$ \\ Mavilde da Luz Gonçalvez Pedreira ${ }^{5}$
}

Objective: To identify predisposing factors for peripheral intravenous puncture failure in children. Methods: Cross-sectional cohort study conducted with 335 children in a pediatric ward of a university hospital after approval of the ethics committee. The Wald Chi-squared, Prevalence Ratio $(P R)$ and backward procedure $(p \leq 0.05)$ tests were applied. Results: Success of peripheral intravenous puncture was obtained in 300 (89.5\%) children and failure in 35 (10.4\%). The failure rates were significantly influenced by: presence of clinical history of difficult venous access, malnourishment, previous use of peripherally inserted central venous catheter, previous use of central venous catheter, and history of phlebitis or infiltration. In the multivariate model, being malnourished and having previously been submitted to central venous catheterization were the predisposing factors for the failure. Conclusion: The failure rate of $10.4 \%$ is similar to that identified in analogous studies and was influenced by characteristics of the children and intravenous therapy. In association with this, malnutrition and previous use of a central venous catheter were the most important variables influencing increase in peripheral intravenous puncture failure.

Descriptors: Pediatric Nursing; Peripheral Catheterization; Patient Safety; Pediatrics.

\footnotetext{
${ }^{1}$ This research was supported by Conselho Nacional de Desenvolvimento Científico e Tecnológico (CNPq), process \# 476295/2004-1. ${ }^{2}$ RN, Student of the specialization course in Nephrology Nursing, Universidade Federal de São Paulo, Brazil.

${ }^{3}$ PhD, Adjunct Professor, Escola Paulista de Enfermagem, Universidade Federal de São Paulo, Brazil.

${ }^{4}$ PhD, Adjunct Professor, Departamento de Bioestatística, Universidade Federal de São Paulo, Brazil.

${ }^{5}$ PhD, Associate Professor, Escola Paulista de Enfermagem, Universidade Federal de São Paulo, Brazil.
} 


\section{Fatores predisponentes para insucesso da punção intravenosa periférica em crianças}

Objetivo: verificar fatores predisponentes para o insucesso da punção intravenosa periférica realizada em crianças. Método: trata-se de estudo de coorte transversal, realizado com 335 crianças internadas em unidade pediátrica de um hospital universitário, após aprovação do mérito ético. Utilizaram-se testes qui-quadrado de Wald, razão de prevalência (RP) e procedimento de backward $(p \leq 0,05)$. Resultados: evidenciou-se sucesso da punção em 300 $(89,5 \%)$ crianças e insucesso em $35(10,4 \%)$. Influenciaram significantemente as proporções de fracasso: apresentar história clínica para dificuldade na punção, estar desnutrido, uso prévio de cateter central de inserção periférica, uso prévio de cateter venoso central e antecedentes de flebite e de infiltração. No modelo multivariado, estar desnutrido e ter sido submetido previamente a cateterização venosa central foram os fatores predisponentes para o insucesso. Conclusões: a proporção de 10,4\% de insucesso na punção é similar à identificada em estudos sobre a temática e foi influenciada por características da criança e da terapia. Em associação, as variáveis desnutrição e uso prévio de cateter venoso central foram as características mais importantes para o aumento da proporção de insucesso da punção intravenosa periférica. Este estudo traz novas evidências sobre os fatores de risco que contribuem para o insucesso na punção intravenosa periférica de crianças, constituindo aspecto a ser considerado no planejamento e execução da prática assistencial de enfermagem pediátrica, com vistas à obtenção de melhores resultados na punção intravenosa periférica e promoção da segurança do paciente.

Descritores: Enfermagem Pediátrica; Cateterismo Periférico; Segurança do Paciente; Pediatria.

\section{Factores predisponentes para fracaso de la punción intravenosa periférica en niños}

Objetivo: Verificar factores predisponentes para el fracaso de la punción intravenosa periférica realizada en niños. Método: Estudio de cohorte transversal realizado con 335 niños internados en unidad pediátrica de un hospital universitario, después de la aprobación del mérito ético. Se utilizaron testes Jue-cuadrado de Wald, Razón de Superioridad (RP) y procedimiento de backward $(p \leq 0,05)$. Resultados: se evidenció éxito de la punción en $300(89,5 \%)$ niños e fracaso en $35(10,4 \%)$. Influenciaron significantemente las proporciones de fracaso: presentar historia clínica para dificultad en la punción, estar desnutrido, uso previo de catéter central de inserción periférica, uso previo de catéter venoso central y antecedentes de flebitis y de infiltración. En el modelo multivariado, estar desnutrido y haber sido sometido antepasadamente a cateterización venosa central fueron los factores predisponentes para el fracaso. Conclusiones: La proporción del 10,4\% de fracaso en la punción es análogo a la identificada en estudios sobre la temática y fue influenciada por características del niño y de la terapia. En asociación, a las variables desnutrición y uso previo de catéter venoso central fueron a las características más importantes para el aumento de la proporción de fracaso de la punción intravenosa periférica. Este estudio trae nuevas evidencias sobre los factores de riesgo que aportan para el fracaso en la punción intravenosa periférica de niños, constituyendo aspecto a ser considerado en la planificación y ejecución de la práctica asistencial de enfermería pediátrica, con vistas a la obtención de mejores resultados en la punción intravenosa periférica y promoción de la seguridad del paciente.

Descriptores: Enfermería Pediátrica; Cateterismo Periférico; Seguridad del Paciente; Pediatría.

\section{Introduction}

Obtaining peripheral intravenous access is the most-commonly carried out invasive procedure in health institutions. It is estimated that more than $70 \%$ of hospitalized patients are subjected to peripheral intravenous puncture (PIP), with the catheters remaining in place for a considerable part of the time that the patients remain hospitalized ${ }^{(1-2)}$.

One of the largest research projects conducted 
on this issue, with 592 children and 1135 attempts at puncture carried out by 143 nurses, observed a rate of failure of $10 \%$, although around $50 \%$ of the first attempts failed. On average, each child was submitted to 2.1 attempts at obtaining intravenous access ${ }^{(3)}$.

Thus, in analyzing this intervention in children, one may observe specific issues related to the anatomical, physiological and cognitive characteristics inherent to the age range, which may influence the intervention's success. Studies undertaken with children have shown failure rates for the procedure varying from 9 to $36 \% \%^{(4-7)}$. The factors which determine the outcome, however, are not well explained in the literature in the area.

Knowing such factors may provide support for advancing changes and innovations in care, so as to obtain results which are safer and more efficient and beneficial for the children. Thus, this study aimed to ascertain characteristics of the children and of the peripheral intravenous therapy (PIT) which may constitute predisposing factors for failure in PIP and sought to determine the predictive or influencing variables for this outcome.

\section{Method}

This is a cross-sectional cohort study, undertaken with 335 children and adolescents submitted to PIP with over-the-needle catheters, hospitalized in the children's surgical unit of a university hospital in São Paulo. These children and adolescents participated in a prospective and randomly interventional study, following the agreement of the children (when possible) and of their parents or guardians to participate in the study.

The present investigation's study variables were obtained based on analysis of the data base of the study mentioned above, after approval by the institution's Research Ethics Committee, Decision \#0402/06, as an addendum.

On admission to the unit where the study was taking place, and after being recommended for the use of PIT, the condition of the peripheral veins was inspected, for evaluation of the places available for PIP. This was based on a scale developed by the researchers, and based on visualization and palpation of the peripheral veins, in accordance with the body segments. In all the children, the catheters were inserted by pediatric nurses with experience in the area of more than one year

The first need for PIP carried out in the child's hospitalization in the unit was considered for analysis. Although the maximum number of attempts at the time of the PIP was not pre-established in care protocols, but no more than four attempts were made. In addition, the last attempt at PIP was considered for analysis.

For this analysis, the obtaining of peripheral intravenous access was considered as a dependent variable, and categorized as 'yes' or 'no'. The definition for 'yes' (success) was the insertion of the catheter into the vein without resistance to progression characterized by blood reflux, infusion of $2 \mathrm{ml}$ of $\mathrm{NaCl} 0.9 \%$, an absence of complaints of pain from the child, and without alteration on inspection and palpation of the catheter insertion site ${ }^{(4,8-9)}$; 'no' (failure) was the absence of the above-mentioned conditions.

The study's explanatory variables were selected considering factors which were intrinsic and extrinsic to the child, which could influence the accomplishment of the PIP. As a result, three groups of variables were selected, relative to the children, to previous PIT, and to the current PIP.

The variables relative to the children were: age in months (calculated by the difference between the data of the PIP and the child's date of birth), sex (male or female), skin color (white/yellow, dark or black) and PIP of the dominant limb (left, right or undetermined). The anthropometric data, weight and stature were evaluated with the aim of identifying the child's nutritional state (malnourished or not), according to the $\mathbf{Z}$ score. The presence of any clinical history which could make PIP difficult (yes or no) was also evaluated these were prematurity, chronic illness, vascular disease, infection, edema, altered peripheral perfusion, muscular spasms, hyperactivity, prolonged surgical treatment, prolonged peripheral intravenous therapy, use of vesicant medications, signs of skin lesions, and others.

For the variables relative to previous intravenous therapy (IVT), the researchers considered the occurrences (yes or no) of: previous hospitalizations, previous use of IVT, type of catheter previously used (peripheral venous catheter - PVC, central venous catheter - CVC, and/or peripherally-inserted central catheter - PICC) and antecedents of phlebitis and infiltrations as local complications of the IVT.

The variables relative to PIP were: use of vascular ultrasonography to guide puncture (yes or no), carrying out preparation of the child with a therapeutic toy or reading and explanatory manuals about the procedure (yes or no), caliber of the catheter (22Gauge (G) or $24 \mathrm{G}$ ), method of puncture (direct or indirect) and use of tourniquet (yes or no). 
The collected data was tabulated in electronic spreadsheets in the data file Statistical Package for the Social Sciences (SPSS), version 15.0. The categorical variables are described with their absolute and relative frequencies, and the numerical variables with averages and standard variations. The associations between the demographic variables, previous IVT and obtaining PIP access were evaluated calculating the prevalence ratio (PR) of not obtaining intravenous access over obtaining successful access. For that purpose, binomial regression models were used, using the Poisson approximation, logarithmic link function and robust variance(10). A backward procedure for removal of variables was used to verify which factors best explain the differences in obtaining peripheral venous access. A significance level of 0.05 was set in all analyses.

\section{Results}

Evidence was provided for the success of PIP in $330(89.6 \%)$ of the 335 children studied, and failure in $35(10.4 \%)$. The reasons for failure were hematoma (18: $51.5 \%)$ followed by vein transfixation $(9 ; 27.5 \%)$, inefficient puncture $(5 ; 14.3 \%)$ and others $(3 ; 8.6 \%)$. The distributions of the children in terms of obtaining of access, according to their demographic characteristics, previous IVT and current PIP, are presented in Tables 1 , 2 and 3, respectively.

As shown in Table 1, the majority of the children were of school age, Caucasian, with the right limb dominant, not malnourished and with homogenous distribution in relation to sex and presence of clinical history of failure in PIP. Among the demographic characteristics, differences were not found between the ratios for failure in relation to age, sex, skin color or which upper limb was dominant. However, statistically significant differences were found in regard to having a clinical history for failure in PIP ( $P R=2.78 ; p=0.004)$ and being malnourished. $(P R=2.32 ; p=0.021)$.

Table 1 - Children's demographic characteristics, in relation to whether peripheral intravenous access was obtained or not

\begin{tabular}{|c|c|c|c|c|c|c|c|}
\hline \multirow{2}{*}{ Variables } & \multirow{2}{*}{$\begin{array}{l}\text { Total } \\
\text { n (\%) }\end{array}$} & \multicolumn{6}{|c|}{ Obtaining of peripheral intravenous access } \\
\hline & & $\begin{array}{c}\text { Yes } \\
\text { n (\%) }\end{array}$ & $\begin{array}{c}\text { No } \\
\text { n (\%) }\end{array}$ & $\chi_{w}{ }^{2 *}$ & $\mathbf{p}^{\dagger}$ & $\mathbf{P R}^{\ddagger}$ & $\mathrm{Cl} 95 \% \S$ \\
\hline Total & $335(100)$ & $300(89.55)$ & $35(10.45)$ & & & & \\
\hline Age (months) & & & & 0.89 & 0.346 & 1.0 & $0.99-1.00$ \\
\hline Average & 92.1 & 92.9 & 77.6 & & & & \\
\hline Minimum-Maximum & $0.4-213.6$ & $0.4-213.6$ & $0.4-204.2$ & & & & \\
\hline \multicolumn{8}{|l|}{ Sex } \\
\hline Male & $187(55.7)$ & $171(91.4)$ & $16(8.6)$ & & & 1 & \\
\hline Female & $148(44.3)$ & $129(87.2)$ & $19(12.8)$ & 1.60 & 0.206 & 1.50 & $0.80-2.82$ \\
\hline \multicolumn{8}{|l|}{ Skin color } \\
\hline White/red & $162(48.4)$ & $147(90.7)$ & $15(9.3)$ & & & 1 & \\
\hline Dark & $123(36.7)$ & $109(88.6)$ & $14(11.4)$ & 0.34 & 0.557 & 1.23 & $0.62-2.45$ \\
\hline Black & $50(14.9)$ & $44(88.0)$ & $6(12.0)$ & 0.32 & 0.569 & 1.30 & $0.53-3.16$ \\
\hline \multicolumn{8}{|c|}{ Clinical history of failure in PIP } \\
\hline No & $176(52.5)$ & $166(94.3)$ & $10(5.7)$ & & & 1 & \\
\hline Yes & $159(47.5)$ & $134(84.3)$ & $25(15.7)$ & 8.09 & 0.004 & 2.78 & $1.37-5.58$ \\
\hline \multicolumn{8}{|l|}{ PIP of dominant limb } \\
\hline Right & $263(78.5)$ & $239(90.9)$ & $24(9.1)$ & & & 1 & \\
\hline Left & $27(8.1)$ & $23(85.2)$ & $4(14.8)$ & 0.94 & 0.333 & 1.62 & $0.61-4.33$ \\
\hline Not determined & $45(13.4)$ & $38(84.4)$ & $7(15.6)$ & 1.80 & 0.180 & 1.71 & $0.78-3.72$ \\
\hline \multicolumn{8}{|l|}{ Nutritional status } \\
\hline Not malnourished & $297(88.7)$ & $270(90.9)$ & $27(9.1)$ & & & 1 & \\
\hline Malnourished & $38(11.3)$ & $30(78.9)$ & $8(21.1)$ & 5.33 & 0.021 & 2.32 & $1.14-4.73$ \\
\hline
\end{tabular}

PIP: Peripheral intravenous puncture, ${ }^{*}$ Wald Chi-squared test; ${ }^{+}$Significance; ${ }^{\ddagger}$ Prevalency Ratio (PR); ${ }^{\S}$ Confidence Interval

The predominant characteristics of previous IVT include: children who had been hospitalized previously, without antecedents of complications, who had used
PIC, but who had not used CVC and/or PICC. It was shown that for determining the predisposing factors in relation to use of IVT prior to the time of puncture, prior 
hospitalization did not present a statistically significant difference. The previous use of IVT and the previous use of PIC were marginally significant. However, previous use of a PICC $(P R=5.14 ; p<0.001)$, previous use of
CVC $(P R=4.06 ; \quad \mathrm{p}<0.001)$ and having antecedents of complications $(P R=2.58 ; \quad p=0.005)$, presented statistically significant differences (Table 2 ).

Table 2 - Characteristics of previous intravenous therapy according to obtaining peripheral venous access or not

\begin{tabular}{|c|c|c|c|c|c|c|c|}
\hline \multirow[b]{2}{*}{ Variables } & \multirow{2}{*}{$\begin{array}{l}\text { Total } \\
\text { n (\%) }\end{array}$} & \multicolumn{6}{|c|}{ Obtaining of peripheral intravenous access } \\
\hline & & $\begin{array}{c}\text { Yes } \\
\text { n (\%) }\end{array}$ & $\begin{array}{c}\text { No } \\
\mathrm{n}(\%)\end{array}$ & $\chi_{w}^{2}$ & $\mathbf{p}$ & PR & $\mathrm{Cl} 95 \%$ \\
\hline Total & $335(100)$ & $300(89.55)$ & $35(10.45)$ & & & & \\
\hline \multicolumn{8}{|c|}{ Previous hospitalization } \\
\hline No & $72(21.5)$ & $67(93.1)$ & $5(6.9)$ & & & 1 & \\
\hline Yes & $263(78.5)$ & $233(88.6)$ & $30(11.4)$ & 1.14 & 0.285 & 1.64 & $0.66-4.08$ \\
\hline \multicolumn{8}{|l|}{ Previous use of IVT } \\
\hline No & $80(23.9)$ & $76(95.0)$ & $4(5.0)$ & & & 1 & \\
\hline Yes & $255(76.1)$ & $224(87.8)$ & $31(12.2)$ & 2.97 & 0.085 & 2.43 & $0.89-6.68$ \\
\hline \multicolumn{8}{|c|}{ Antecedents of complications } \\
\hline No & $290(86.6)$ & $265(91.4)$ & $25(8.6)$ & & & 1 & \\
\hline Yes & $45(13.4)$ & $35(77.8)$ & $10(22.2)$ & 7.84 & 0.005 & 2.58 & $1.30-5.00$ \\
\hline \multicolumn{8}{|l|}{ Use of PIC } \\
\hline No & $83(24.8)$ & $79(95.2)$ & $4(4.8)$ & & & 1 & \\
\hline Yes & $252(98.8)$ & $221(87.7)$ & $31(12.3)$ & 3.30 & 0.069 & 2.55 & $0.93-7.02$ \\
\hline \multicolumn{8}{|l|}{ Use of CVC } \\
\hline No & 301 (89.9) & $227(90.4)$ & $24(9.6)$ & & & 1 & \\
\hline Yes & $34(13.3)$ & $23(67.6)$ & 11 (32.4) & 19.65 & $<0.001$ & 4.06 & $2.18-7.54$ \\
\hline \multicolumn{8}{|l|}{ Use of PICC } \\
\hline No & $329(98.2)$ & $297(90.3)$ & $32(9.7)$ & & & 1 & \\
\hline Yes & $6(2.4)$ & $3(50.0)$ & $3(50.0)$ & 13.75 & $<0.001$ & 5.14 & $2.16-12.21$ \\
\hline
\end{tabular}

IVT; peripheral intravenous therapy; PIC: peripheral intravenous catheter; CVC: central venous catheter; PICC peripherally-inserted central catheter; $\chi_{\mathrm{w}}{ }^{2}$ : Wald Chi-squared test; PR: Prevalency Ratio; CI: Confidence Interval

Regarding the characteristics of the materials and techniques used, the majority of the children received preparation before the procedure, the most-used method for puncture was 'indirect', with a 24G catheter and use of a tourniquet. When the outcome is associated with the variables relative to the current PIP, it may be verified that the use of US to guide the puncture, along with the method of puncture, did not present a significant association with the PIP's failure. The preparation of the child for the procedure, the calibre of catheter and the use of a tourniquet on the limb, however, showed marginal significance (Table 3 ).

Table 3 - Characteristic of the current peripheral intravenous puncture according to obtaining peripheral intravenous access or not

\begin{tabular}{|c|c|c|c|c|c|c|c|}
\hline \multirow[b]{2}{*}{ Variables } & \multirow[b]{2}{*}{$\begin{array}{l}\text { Total } \\
\text { n (\%) }\end{array}$} & \multicolumn{6}{|c|}{ Obtaining of peripheral intravenous access } \\
\hline & & $\begin{array}{c}\text { Yes } \\
\text { n (\%) }\end{array}$ & $\begin{array}{c}\text { No } \\
\text { n (\%) }\end{array}$ & $\chi_{w}{ }^{2}$ & p & PR & $\mathrm{Cl} 195 \%$ \\
\hline Total & $335(100)$ & $300(89.55 \%)$ & $35(10.45 \%)$ & & & & \\
\hline \multicolumn{8}{|l|}{ Use of US } \\
\hline No & $164(49.0)$ & $151(92.1)$ & $13(7.9)$ & & & 1 & \\
\hline Yes & $171(51.0)$ & $149(87.1)$ & $22(12.9)$ & 2.12 & 0.145 & 1.62 & $0.85-3.11$ \\
\hline \multicolumn{8}{|c|}{ Preparation of the child } \\
\hline Yes & $312(93.1)$ & $282(89.6)$ & $30(10.4)$ & & & 1 & \\
\hline No & $23(6.9)$ & $18(78.3)$ & $5(21.7)$ & 3.57 & 0.059 & 2.26 & $0.97-5.27$ \\
\hline \multicolumn{8}{|c|}{ Caliber of the catheter } \\
\hline $22 \mathrm{G}$ & $61(18.2)$ & $57(98.3)$ & $1(1.7)$ & & & 1 & \\
\hline
\end{tabular}


Table 3 - (continuation)

\begin{tabular}{|c|c|c|c|c|c|c|c|}
\hline \multirow[b]{2}{*}{ Variables } & \multirow[b]{2}{*}{$\begin{array}{l}\text { Total } \\
\mathrm{n}(\%)\end{array}$} & \multicolumn{6}{|c|}{ Obtaining of peripheral intravenous access } \\
\hline & & $\begin{array}{c}\text { Yes } \\
\text { n (\%) }\end{array}$ & $\begin{array}{c}\text { No } \\
\text { n (\%) }\end{array}$ & $\chi_{w}{ }^{2}$ & $\mathbf{p}$ & PR & $\mathrm{Cl} 95 \%$ \\
\hline $24 G$ & $274(81.8)$ & $243(87.7)$ & $34(12.3)$ & 3.82 & 0.051 & 7.12 & $0.99-50.96$ \\
\hline \multicolumn{8}{|l|}{ Method of puncture } \\
\hline Direct & $132(39.4)$ & $119(90.2)$ & $13(9.8)$ & & & 1 & \\
\hline Indirect & $203(60.6)$ & $181(89.2)$ & $22(10.8)$ & 0.08 & 0.773 & 1.10 & $0.58-2.11$ \\
\hline \multicolumn{8}{|l|}{ Use of tourniquet } \\
\hline Yes & $328(97.9)$ & $295(89.9)$ & $33(10.1)$ & & & 1 & \\
\hline No & $7(2.1)$ & $5(71.4)$ & $2(28.6)$ & 2.83 & 0.092 & 2.84 & $0.84-9.57$ \\
\hline
\end{tabular}

US: Ultrasound; $\chi_{\mathrm{w}}{ }^{2}$ : Wald Chi-squared test, PR: Prevalency Ratio; CI: Confidence Interval

The multivariate model, as shown in Table 4, demonstrated - associated with PIP failure rate - malnutrition ( $\mathrm{PR}=2.15$ CI 95\% $[1.09 ; 4.23])$ and previous use of CVC (PR=3.90 CI 95\% $[2.12 ; 7.20])$.

Table 4 - Final adjusted multivariate model

\begin{tabular}{lcccc}
\hline \multicolumn{1}{c}{ Variables } & $\begin{array}{c}\text { No obtaining of PIVA } \\
(\mathbf{\%})\end{array}$ & $\mathbf{X w 2}$ & $\mathbf{p}$ & $\mathbf{R P}$ \\
\hline Malnutrition & $15.2 \%$ & 4.93 & 0.026 & 2.15 \\
Previous use of CVC & $27.6 \%$ & 19.11 & $<0.001$ & 3.90 \\
\hline
\end{tabular}

CVC: central venous catheter; PIVA: peripheral intravenous access; $\chi_{w}{ }^{2}$ : Wald Chi-squared test, PR: Prevalency Ratio; CI: Confidence Interval

\section{Discussion}

In the present study, the researchers analyzed the predisposing factors to failure of PIP, compared proportionately to the group which obtained success in puncture. Failure in PIP was evidenced in 10.4\% of the children, a proportion which is found in studies undertaken in the area of pediatry in other countries ${ }^{(5-7)}$. Research on adults shows similar failure $\operatorname{rates}^{(4,9)}$.

The most prevalent reason for failure in PIP was hematoma, in around half of the patients. So as to prevent this type of complication, attention should be drawn to the positioning of the tourniquet as distal as possible to the area of insertion of the catheter, with a view to reducing intravascular pressure ${ }^{(11)}$ and, therefore, reduce the chance of rupturing the vessel in the moment of puncture. Recognizing the possible reasons for failure can help the health professional in the preventive management of potential causes through the use of techniques such as the appropriate use of the tourniquet. However, as the use of the tourniquet was predominant, it was not possible to analyze the technique's influence in the results obtained of failure.

The children's non-alterable factors, such as age, sex and skin color, do not show contribution to PIP failure, which corroborates other studies(4,7,12-13). However, authors discount the possibility that being female and having dark skin or extreme age impede the obtaining of access; the reasons mentioned result from the smaller caliber of the veins and difficulty in evaluating the vessel ${ }^{(4,14-15)}$.

It was evidenced that the malnourished children presented a statistically significant difference for failure to obtain PIP, with a prevalence ratio for failure of 2.32 . Malnourishment, according to a Brazilian study, is prevalent on admission to hospital of children but is not diagnosed in them ${ }^{(16)}$. One can highlight capillary fragility and reduction in tissue turgor among the reasons which lead to PIP failure in malnourished children.

In daily practice, puncture of children in the infant age range, in which the proportion of body fat is comparatively higher than in other age ranges, is widely seen as PIP's biggest difficulty, a fact which is not identified as a risk for PIP failure ${ }^{(13)}$. A recent study undertaken by anesthetists with the aim of demonstrating the relationship between body mass index and facility of access showed that obese children present a higher probability of failure when compared to thin children and, therefore need further attempts at puncture ${ }^{(17)}$. Studies report that excess weight makes it difficult to visualize and palpate the venous network, thus contributing to failure in puncture ${ }^{(14,17)}$. The researchers in the present study, however, did not observe this association, in view of the restricted number 
of children with this characteristic, a factor which may have interfered in the result.

A positive case history for difficulty in PIP, evaluated by the nursing team, is shown to increase the risk of failure in PIP by a factor of approximately two and a half. Among these characteristics, prematurity, chronic illness, prolonged surgical treatment, prolonged peripheral IVT and the use of medications stood out. Authors cite that some of these conditions can impede success in the procedure $(4-5,7,14,18-19)$. In the present study, however, the researchers did not identify which clinical condition was most significant, due to the high number of associations between the same for each child.

In terms of the planning of the nursing care practice in undertaking IVT, case history and patient history are fundamental to the collection of data when the child is admitted, as they support the subsequent stages of the nursing process ${ }^{(20)}$. This being so, it is important to value the children's hospital antecedents, and the antecedents of IVT, considering that these contain valuable information which allows the nurse to adopt the best conduct in partnership with the multidisciplinary team. The raising of data from parents and family members, as well as from the child's medical notes, is an indispensable source of information about the child's health history.

In relation to the variables related to previous IVT, it should be noted that the children who presented puncture failure had already been hospitalized before, had undergone IVT, and used PIC, but these situations did not associate statistically, or were marginal. However, a previous history of complications related to catheter use increased the risk of failure in the puncture attempt by 2.58 times. There is no evidence in the literature about the presence of previous complications in pediatric patients in relation to PIP failure. A study with adults hypothesizes that previous complications from catheter-use-related phlebitis harm the peripheral veins and increase the likelihood of the occurrence of future complications ${ }^{(21)}$. The recognition of this and other local complications, such as infiltration, are reasons for the removal of the catheter ${ }^{(22-23)}$. It follows that the establishment of a new intravascular route for continuance of the therapy becomes necessary.

CVC is adopted under medical advice which takes various aspects into account. Among the reasons for CVC use, one should highlight difficulty identified in obtaining peripheral intravenous access. For the installation of a PICC line, on the other hand, the taking of the decision follows an inverse path, that is, it is necessary for there to be a healthy peripheral vein for catheter introduction, which has not been the subject of failed attempts in the past $^{(24)}$. The use of a centrally-placed catheter is more related with serious adverse events when compared to a PIC; it is necessary to identify methods and technology which promote greater effectiveness and possible use, for longer periods of time, of the peripheral route for insertion of catheters ${ }^{(25)}$. In the present study, it was demonstrated that the previous use of CVC $(P R=5.14)$ and PICC $(P R=4.06)$ presented statistical significance for failure.

Researchers have committed themselves to collecting together technological innovations in the practice of puncture, among which the present study's authors emphasize the use of US. They point to the number of attempts at puncture, less time spent on the procedure, less redirecting of the catheter, and to patient satisfaction ${ }^{(5,7,9,13)}$. The present study did not identify a significant association between the use of US and success in PIP. The same was observed in relation to the preparation of the child for the procedure and to the caliber of the catheter used; the use of a tourniquet on the limb had marginal significance. It is possible that the various previous attempts may have guided the adaptation of the technique. It is worth emphasizing that the hospital ward where the study took place had trained and experienced pediatric nurses available, who carried out all the punctures.

When associated with the conditions which presented a significant difference in the proportion of failure in PIP, it was malnourishment and previous use of CVC which, together, most increased the probability of failure, of 2.15 and 3.90 times, respectively.

Thus, to guide the professionals involved to adopt behaviors which aim to prevent harm, it is essential to observe the dyad of factors - intrinsic and extrinsic which predispose a child to failure in obtaining peripheral venous access.

\section{Conclusion}

The univariate analysis showed a statistically significant influence on failure from the variables: clinical history of difficulty in PIP, malnourishment, previous use of PICC, previous use of CVC, and antecedents of complications from IVT in the form of phlebitis and infiltration. When the set of variables was subjected to multivariate analysis, it was found that in relation to the children's characteristics, the most important variables for increase in the PIP failure rate were being 
malnourished and having previously received IVT by CVC.

It may therefore be concluded that the children who presented one or more of these characteristics or conditions presented a higher risk of failure in PIP, which constitutes important evidence for pediatric nursing care practice, highlighting the importance of identifying existing factors and conditions, as well as the previous experiences of the child submitted to peripheral intravenous therapy, with a focus on obtaining better results.

Limitations of the study: The fact that the study was carried out in a single center may be considered a limiting factor. The undertaking of further, multi-centric, research, so as to study populations of children with different characteristics, is relevant.

\section{Acknowledgement}

To the children and families who enabled the accomplishment of the research, the nursing and medical teams of the research institution.

\section{References}

1. Zingg W, Pittet D. Peripheral venous catheters: an under-evaluated problem. Int J Antimicrob Agents. 2009;34(Suppl 4):S38-42.

2. Machado AF, Pedreira MLG, Chaud MN. Adverse events related to the use of peripheral intravenous catheters in children according to dressing regimens. Rev. LatinoAm. Enfermagem. 2008;16(3):362-7.

3. Larsen P, Eldridge D, Brinkley J, Newton D, Goff D, Hartzog T, Saad ND, Perkin R. Pediatric peripheral intravenous access: does nursing experience and competence really make a difference? J Infus Nurs. 2010;33(4):226-35.

4. Jacobson AF, Winslow EH. Variables influencing intravenous catheter insertion difficulty and failure: An analysis of 339 intravenous catheter insertions. Heart \& Lung. 2005;34(5):345-359.

5. Doniger SJ, Ishimine P, Fox JC, Kanegaye JT. Randomized Controlled Trial of ultrasound - guided peripheral intravenous catheter placement versus traditional techniques in difficult - Access pediatrics patients. Pediatric Emergency Care. 2009;25(3):154-9.

6. Lininger RA. Pediatric peripheral IV insertion success rates. Pediatr Nurs. 2003;29(5):351-4.

7. Yen K, Riegert A, Gorelick MH. Derivation of the DIVA Score: A clinical prediction rule for the identification of children with difficult intravenous Access. Pediatric Emergency Care. 2008;24(3):143-7.
8. Milling JT, Rose J, Briggs WM, Birkhahn R, Gaeta TJ, Bove JJ, et al. Randomized, controlled clinical trial of point-of-care limited ultrasonography assistance of central venous cannulation: The third sonography outcomes assessment program (SOAP-3) trial. Crit Care Med. 2005;33(8):1764-9.

9. Constantino TG, Parikh AK, Satz WA, Fojtik JP. Ultrasonography-guided peripheral intravenous Access versus traditional approaches in patients with difficult intravenous Access. Annals Emergency Med. 2005;46(5):456-61.

10. Barros JD, Hirakata VN. Alternatives for logistic regression in cross-sectional studies: an empirical comparison of models that directly estimate the prevalence ratio. BMC Med Res Methodol. 2003;3:21.

11. Mbamalu D, Banerjee A. Metholds of obtaining peripheral venous Access in difficult situations. Postgrad Med F. 1999;75:459-462.

12. Lapostolle F, Catineau J, Garrigue B, Monmarteau V, Houssaye T, Vecci I, et al. Prospective evaluation of peripheral venous Access difficulty in emergency care. Intensive Care Med. 2007;33:1452-7.

13. Simhi E, Kachko L, Bruckheimer E, Katz J. A vein entry indication device for facilitating peripheral intravenous cannulation in children: a prospective, randomized, controlled Trial. Anesth Analg. 2008;107(5):1531-5.

14. Nikolaus $A H$. Clinical review: vascular Access for fluid infusion in children. Crit Care. 2004;8(6):478-84.

15. Roberge RJ. Venodilatation techniques to enhance venepuncture and intravenous cannulation. J Emergency Med. $2004 ; 27(1): 69-73$.

16. Ferreira HS, França AOS. Evolução do estado nutricional de crianças submetidas à internação hospitalar. J Pediatric. 2002;78(6):491-6.

17. Nafiu OO, Burke C, Cowan A, Tutuo N, Maclean $\mathrm{S}$, Tremper KK. Comparing peripheral venous Access between obese and normal weight children. Pediatric Anesthesia. 2010;20:172-6.

18. Blaivas M, Lyon M. The effect of ultrassound guidance on the perceived difficult of emergency nurse obtained peripheral IV Access. J Emerg Med. 2006;31(4):407-10. 19. Rauch D, Dowd D, Eldridge D, Mace S, Schears G, Yen K. Peripheral diffiuclt venous Access in children. Clin Pediatrics. 2009;48(9):895-901.

20. Cunha, SMB; Barros, ALBL. Análise de implementação da Sistematização da Assistência de enfermagem, segundo o Modelo Conceitual de Horta. Rev Bras Enferm. 2005;58(5):568-72.

21. Pettit J. Assesment of the infant with a peripheral intravenous device. Adv Neonatal Care. 2003;3(5):230-40. 
22. Senna CA, Carvalho EC. Avaliação de punção venosa periférica: análise de critérios de remoção de dispositivo intravenoso adotados por uma equipe de enfermagem. Esc Anna Nery. 2003;7(3):351-360.

23. Waitt $C$, Waitt $P$, Pirmohamed $M$. Intravenous Therapy. Postgrad Med J. 2004;80(939):1-6.

24. Maki DG, Ringer M. Risk factors for infusion-related phlebitis with small peripheral venous catheters: a randomized controlled trial. Ann Intern Med. 1991;114:845-54.

25. Franceschi AT; Cunha MLC. Adverse events related to the use of central venous catheters in hospitalized newborns. Rev. Latino-Am. Enfermagem. [periódico na Internet]. mar-abr 2010 [acesso 16 set 2012]; 18(2):196-202. Disponível em: http://www. scielo.br/scielo.php?script =sci_arttext\&pid=S01041692010000200009\&Ing=en. http://dx.doi. org/10.1590/S0104-11692010000200009. 